\title{
An Analysis of the Stock Market Volatility Spread in Emerging Countries
}

\author{
Murat Akkaya1 1
}

\begin{abstract}
This article provides results on the volatility spread for stock markets in emerging economies. Empirical studies on determining or predicting volatility in national and international financial markets provide information for investors. The aim of this study is also to analyze volatility spreads from the United States of America, France, Germany, Japan Turkey, China, India, Indonesia from emerging markets within the scope of EGARCH models, which take into account the asymmetric effects using daily stock returns for the period of January 2008 - April 2020. The a symmetric effect parameter ( $\lambda$ or $\mu \mathrm{t}-\mathrm{i} / \mathrm{ht}-1$ ) appears to be negative and statistically significant at $1 \%$ for all countries, except the Shanghai Composite Stock Exchange, China. This result shows that the asymmetric effect, or the leverage effect in other words, is valid in stock markets other than China. The volatility spreads from the Dow Jones Industrial Average Index - USA to Borsa Istanbul and the Shanghai Stock Exchange - China. Also, the S \& P 500 Index - USA is significant on the volatility spread of the Borsa Istanbul and Shanghai Stock Exchange. The volatility spread between Jakarta Stock Exchange - Indonesia and Borsa Istanbul is two-way and mutual.
\end{abstract}

\section{Keywords}

Volatility, Contagion, Stock Market, E-Garch, Emerging Countries

\section{Introduction}

The concept of volatility means "sudden leaps up and down," "sudden change" or "variability." Financial globalization, technological innovations, competition and foreign capital investments increase the interdependence of financial markets and lead to the spread of volatility between markets. Volatility spread begins with a shock occurring in a market that increases volatility in other markets. Stock price volatility is also a sudden variation in the price of any security. Volatility can make stock investments risky and affects investors' decision making processes in financial markets by creating uncertainty. Thus, return, volatility and 
their interactions should be taken into consideration to realize an effective portfolio management. Also, the protection of investors in the capital market is closely related to the concept of an efficient market. However, unexpected events such as Corona Virus (COVID-19) cause sudden changes in the prices of financial assets. In other words, they cause significant and high volatility in asset prices. High levels of volatility mean high risk, which further increases the need to measure risk and provide protection from those risks. The volatility spread occurs when the prices determined by investors trading in the international financial markets are affected by the information flow. The United State of America Central Bank (Fed) announced that it would start to decrease bond purchases on May 22, 2013. Then, foreign investment funds flowing into the emerging market economies started to decrease. The Fed also started to increase interest rates in December 2016 after a 10-year break. The Fed increased the funding interest rate to $2.25-2.50$ percent on December 19, 2018. Volatility in the markets of emerging countries increased in parallel with the Fed's increasing funding interest rates. The turbulence experienced in international financial markets in the last 20-25 years and the intensive uses of derivative products for the purpose of hedging and speculative income lead to huge interest in forecasting the actions in financial markets. Thus, many studies have been conducted to model volatility in financial markets. Volatility is a measure of the width of a series relative to the rhythm of deviation from a certain mean. When the risk of the series is revealed, the knowledge of the volatility structure can serve as an input in investors' decisions (Gujarati, 2011). In order to model the volatility in the financial time series, it is necessary to determine the features such as kurtosis, volatility clustering and the leverage effect first introduced by Black (1976). The variances of errors in the financial time series are not stationary, but they are also usually heteroscedastic. Thus, traditional time series analysis models based on the homoscedasticity assumption are insufficient. Engle (1982) developed the Autoregressive Conditional Heteroscedasticity (ARCH) model to predict the variance varying over time by considering the dynamic structure of financial assets. Both the presence of various restrictions on the $\mathrm{ARCH}$ model and the existence of drawbacks such as negative parameter estimates are eliminated with the model developed by Bollerslev (1986) and the ARCH model has been converted into the GARCH (Generalized Autoregressive Conditional Heteroscedasticity) model.

The Corona Virus (COVID-19) epidemic, which started in China at the end of December 2019 , increased the volatility in the stock and foreign exchange markets and created significant pressure for the markets. This study examines the impact of volatility on stock markets in emerging countries. The aim of the study is to analyze volatility spreads in United States of America (USA), France, Germany, Japan from developed markets and Turkey, China, India, Indonesia from emerging markets within the scope of EGARCH models, which take into account the asymmetric effects using daily stock returns for the period of January 2008 - April 2020. 


\section{Motivation}

Determining the mechanism of the spread of volatility from one market to another will initially guide investors in the decision-making process. In addition, it will provide important information to policymakers regarding the evaluation of relations between markets and policy making within this scope. Thus, the spread of volatility between stock markets has a large place in finance literature. But the studies on the relationship between expected returns and volatility have conflicting results. Most of them examine developed countries' markets, particularly the U.S. stock market, and typically employ ARCH and GARCH models instead of linear time series models. Earlier studies determined a positive and significant relationship (French et al. 1987; Eun \& Shim, 1989). The volatility spreads from the USA towards Japan and England and from England to Japan (Hamao et al. 1990). Sheng and Tu (2000) emphasize that the US stock market index has a dominant effect on Asian countries during the crisis period. But Baillie and DeGennaro (1990), Shin (2005) and Theodossiou and Lee (1995) observe a positive but insignificant effect.

ARCH models, called volatility models, started to be used in the literature with the emergence of time series with heteroscedasticity by Engle (1982). Another type of study is on the asymmetric volatility spread in financial markets. GARCH models are generally preferred in such studies. Kanas (1998) examines the volatility spread in London, Frankfurt and Paris stock markets with the EGARCH model for the period of 01.01.1984-12.07.1993. A mutual relationship between London-Paris and Paris-Frankfurt occurs. One-way spread occurs from London to Frankfurt. These markets are more interconnected in the post-collapse period. Ng (2000) shows the magnitude of the volatility spread from Japan and the USA towards stock markets in six Pacific markets using the two-variable GARCH (1.1) model. Features such as liberalization, exchange rate changes, and trade size significantly affect the world and regional market over time. Volatility spreads from Hong-Kong, the USA, Japan and UK stock markets towards Singapore (Bala \& Premaratne, 2004). The volatility of Asian stock exchanges is more affected by the Japanese stock market than the US stock market (Miyakoshi, 2003). Engle et al. (2012) investigated the daily volatility spread in eight East Asian markets for the period 1995-2006 by the Multiplication Error Model. The September 2001 terrorist aggression had little effect and the Asian crisis swell outs the spread of the volatility. Also, volatility spread among 6 Asian exchanges increased after the Asian crisis (Lee, 2009). Volatility spread and effects are available in CAC40-French Stock Market Index, DAX-German Stock Market Index, FTSE100 - England Stock Market Index and S\&P 500 Index - USA in the period of 05.01.2004 - 01.01.2009 using the BEKK GARCH and DCC GARCH model (Xiao \& Dhesi, 2010). Significant information flows from Hong Kong, Korea, Singapore and Thailand to India without many lags. The unforwarded information reaches the markets the next day (Mukherjee \& Mishra, 2010). The USA stock index significantly affects Egypt and Israel stock indices (Abou-Zaid, 2011). Also, continuous volatility spread from the 
USA to South Africa occurs (Yonis, 2011). Joshi (2011) examines the return and volatility spread in Asian stock markets with the GARCH-BEKK model using data from 02.02.200729.02.2010. It turns out that bilateral returns, shock and volatility spread among most of the stock exchanges, and their volatility spreads are more than cross volatility spreads. The bad news in the stock markets of the six emerging countries (Brazil, Russia, Mexico, India, China, South Africa) have a greater impact on the volatility of prices, and negative shocks in stock returns cause disproportionate increases in volatility (Tripathy \& Garg, 2013). Considering the pre-crisis and crisis period, volatility in the US markets affects both the Euro and Emerging Market Economies, but it is not affected by any of these markets. In addition, volatility in emerging markets has an impact on eurozone volatility in both periods, but volatility in the eurozone does not affect emerging markets in the pre-crisis period (Büberkökü, 2013). The United States and Islamic stock markets (Turkey, Indonesia, Pakistan, Qatar, Malaysia) had a weak relationship for the period of January 2008-January 2013 (Majdoub \& Mansour, 2014). For the eight major economies of the Asia/Pacific region in the period 1997-2013, volatility spread was more pronounced compared to the contagion effect (Islam et al. 2013), The four stock indices in China have also a very strong ARCH effect on returns (Xie \& Huang, 2013). However, in the period of 01.01.2007-31.12.2013, US market news significantly affected BRICS (Brazil, Russia, India, China and South Africa) markets except Brazil and China (Kishor \& Singh, 2014). Also, significant returns and volatility spreads occur between the US and BRICS exchange rates and trading sectors (Syriopoulos et al. 2015). Li and Giles (2015) report a one-way volatility spread from the USA to Japan and other Asian countries. In the stock returns between 1994 and 2016, the relationships between emerging markets were lower than those between developed markets and tended to increase during financial crises (Bala \& Takimoto, 2017). In the period of January 1999 - January 2015, the volatility of the Malaysia stock exchange and 14 developed and developing country stock exchanges is related not only to its lagged values but also to the spread of volatility from other countries. Also, significant volatility spread occurs on the Malaysian stock market, which is evidence of the growing market integration of most of the stock indices (Qian \& Diaz, 2017). In the period of 09.12.2008-01.22.2016, both one-way and two-way volatility spreads occured between the stock markets of Developed 7 countries. There is evidence of asymmetric causal relationships between volatility shocks (Özer et al. 2016).

The determination of volatility spread and testing of volatility models in indices within Borsa Istanbul have become widespread especially since the 2000s, and Borsa Istanbul 100 Index volatility has an ARCH effect (Doğanay, 2003; Duran \& Şahin, 2006; Akgün \& Sayyan (2007); Sevüktekin \& Nargeleçekenler, 2006; Atakan, 2009). After the 2008 financial crisis, studies testing the effects of volatility on Borsa Istanbul Stock Exchange with the help of GARCH models have increased significantly (Tülin, 2009, Çağıl \& Okur, 2010; Yorulmaz \& Ekici, 2010; Güriş \& Saçıldı, 2011; Demir \& Çene, 2012; Evlimoğlu \& Çondur, 2012; Çukur 
et al. 2012; Kutlar \& Torun, 2013; Er \& Fidan, 2013; Samırkaş \& Düzakın, 2013; Demirhan, 2013; Demirgil \& Gök, 2014; Karabacak et al. 2014; Gürsoy \& Balaban, 2014; Gökbulut \& Pekkaya, 2014; Eryılmaz, 2015, McMillan et al. 2016; Kırkulak \& Ezzat, 2017, Baykut \& Kula, 2018; Kocabaş, 2019,). In addition to GARCH models, the EGARCH model can estimate volatility, taking into account the asymmetry of the shocks. Y1ldiz (2016) tests the validity of the conditional variance models in Borsa Istanbul with daily data covering the period between January 05, 2000 and December 9, 2015. The returns on the stock exchange are more affected by the negative or bad news coming to the market and volatility in the indices is valid. Following the shocks experienced in the emerging markets, permanent deviations occur in the returns of the stock markets. Negative shocks increase volatility compared to positive shocks, and the volatility spread mechanism between the markets is asymmetrical (Bayramoğlu \& Abasız, 2017). Değirmenci and Abdioğlu (2017) analyze the volatility spread from USA, Canada, China, Japan, South Korea, Germany, Britain, Switzerland and Greece to fragile markets (Brazil, India, Indonesia, South Africa, Turkey, Hungary, Poland and Chile) between January 2006 and June 2015 with the EGARCH model. Except for the American, Asian and European stock markets and Indonesia, the leverage effect for the fragile octets' stock markets and the volatility spread from the stock markets of developed countries towards the stock markets of the fragile octets take place. For the period of 2013 - 2017, Indonesia, Mexico, Nigeria, the Philippines and Turkey stock markets have no advantage over the others in terms of information and market efficiency. Similar to the spread of returns, information shocks spread asymmetrically across countries (Çelik et al. 2018). Turkey and United Kingdom stock markets don't expose to volatility spread from other markets, but it takes place in Germany, China and Russia for the period of 2011-2016 (Dedi \& Yavaş, 2016). Except for the stock markets of America, Indonesia, Asia and Europe, there is a leverage effect in the stock markets of fragile countries and the volatility spreads from developed markets to the fragile markets. The stock markets of Indonesia, Mexico, Nigeria, the Philippines and Turkey had no superiority over others in terms of information and market efficiency in the 2013 2017 period. Similar to the spread of returns, information shocks also spread asymmetrically between countries (Çelik et al. 2018). Turkey and UK stock markets were not exposed to the volatility spread from other markets, but the volatility spread occurred in Germany, China and Russia for the period of 2011-2016 (Dedi and Yavaş, 2016).

\section{Data and Methodology}

An economic crisis could spread to other economies for unexplained reasons. The term "contagion" was first proposed by Masson (1998) to distinguish this sprawl from those based on economic connections. The process in question is described by Dornbusch et al. (2000) and is defined as "irrational events" and "financial contagion," which is also defended by the World Bank. Fry et al. (2008) uses the contagion effect to describe changes in the moments of distribution during a financial crisis that cannot be explained by market fundamentals. 
Volatility spread is also another type of contagion. Thus, this study attempts to determine volatility spreads of United States of America (USA), France, Germany Japan from developed countries and Turkey, China, India, Indonesia from emerging markets using daily stock returns for the period of January 2008 - April 2020 and covers nine countries and 3.108 observations. Thus, this study attempts to determine volatility spreads from developed markets to emerging markets using daily stock returns for the period of January 2008 - April 2020 and covers nine countries and 3,108 observations. Table 1 shows variables and abbreviations. The null hypothesis of this study is that there is no volatility spread among emerging markets stock exchanges. The alternative hypothesis is that there is a volatility spread among emerging markets stock exchanges.

Table 1

Variables

\begin{tabular}{lc}
\hline Abbreviation & Variable \\
\hline BIST100 & Borsa İstanbul 100 Return Index - Turkey \\
DOW JONES & Dow Jones Industrial Average Index - USA \\
SP 500 & S\&P 500 Index -USA \\
NIKKEI 225 & Tokyo Stock Market Exchange - Japan \\
DAX & German Stock Market Index \\
CAC40 & French Stock Market Index \\
INDIA & NIFTY 50 - India Stock Market Index \\
SHANGHAI & Shanghai Composite Stock Exchange - China \\
INDONESIA & Jakarta Stock Exchange - Indonesia \\
BOVESPA & Brazil Stock Exchange \\
\hline
\end{tabular}

Source: Author

Descriptive statistics of the stock markets of developed countries are shown in Table 2.

Table 2

Descriptive statistics of the stock markets of developed countries for the period of January 2008 - April 2020

\begin{tabular}{lccccc} 
& SP 500 & DOW & DAX & CAC40 & NIKKEI \\
\cline { 2 - 5 } Mean & 2479.52 & 16611.52 & 8970.97 & 4333.27 & 15225.96 \\
Median & 1846.11 & 16179.37 & 9250.10 & 4318.60 & 15157.20 \\
Maximum & 29551.42 & 29551.42 & 13789.00 & 6111.24 & 24270.62 \\
Minimum & 676.53 & 6547.05 & 3666.41 & 2519.29 & 7054.980 \\
Std. Dev. & 4018.68 & 5690.21 & 2678.42 & 795.98 & 5012.80 \\
Skewness & 5.69 & 0.47 & 0.01 & 0.07 & 0.11 \\
Kurtosis & 34.88 & 2.13 & 1.68 & 2.07 & 1.62 \\
Jarque-Bera & 148476.70 & 209.92 & 225.82 & 113.71 & 254.29 \\
Sum & 7706373 & 51628591 & 27881790 & 13467812 & 47322296 \\
Observations & 3108 & 3108 & 3108 & 3108 & 3108 \\
\hline
\end{tabular}

DOW has the highest standard deviation, and CAC40 has the lowest standard deviation. The skewness coefficients of the stock returns series of all countries are positive. In other words, the distribution of returns is right-skewed. Jarque-Bera statistics show that the series are normally distributed. 
Descriptive statistics of the emerging countries' stock markets are presented in Table 3.

Table 3

Descriptive statistics of the stock markets of emerging market for the period of January 2008 - April 2020

\begin{tabular}{lcccc} 
& BIST100 & BOVESPA & INDIA & INDO \\
\cline { 2 - 5 } Mean & 73487.05 & 64066.48 & 7258.12 & 4401.87 \\
Median & 75476.30 & 60760.50 & 6324.78 & 4584.84 \\
Maximum & 123556.10 & 119528.00 & 12362.30 & 6689.28 \\
Minimum & 21228.30 & 29435.00 & 2524.20 & 1111.36 \\
Std. Dev. & 22558.89 & 16755.52 & 2494.26 & 1407.22 \\
Skewness & $-0,16$ & 1.16 & 0.32 & $-0,49$ \\
Kurtosis & 2.53 & 4.17 & 2.01 & 2.34 \\
Jarque-Bera & 42.58 & 868.80 & 177.98 & 179.49 \\
Observations & 3108 & 3108 & 3108 & 3108 \\
\hline
\end{tabular}

Source: Author

Borsa İstanbul, Turkey has the highest standard deviation and Jakarta SME, Indonesia has the lowest standard deviation. Bovespa and Indian SME are right-skewed as Borsa İstanbul, Turkey and Jakarta SME, Indonesia are left-skewed. The kurtosis coefficients of all countries' return series except BOVESPA are greater than 3. In other words, they are leptokurtic. Jarque-Bera statistics show that the series are not normally distributed.

GARCH model is the one of best explanatory methods to determine the asymmetrical effect of the volatility spread from a stock market to another and the shocks in the stock markets. EGARCH is a widely used method to detect the asymmetric effect in the stock markets, or in other words, leverage effect. Thus, this study prefers the EGARCH model.

In classical linear regression models, the variances of the error terms of the predicted models are assumed to be constant over time, in other words, homoscedastic. However, it has been observed that the variance of the error term can be changed in the findings resulting from the estimation of econometric models that use both horizontal section and time series data. In the literature, this is called Heteroscedasticity. Thus, the constant variance assumption in traditional time series models is abandoned. It is possible to model the conditional mean and variance of a series simultaneously with the Autoregressive Conditional Heteroscedastic $(\mathrm{ARCH})$ model that was introduced to the econometrics literature by Engle (1982). The Generalized ARCH (GARCH) model, which is the extension of the ARCH model, was developed by Bollerslev (1986) in order to overcome the practical difficulties of the ARCH model. The difference of the GARCH model from the ARCH model is that conditional variance lags are also included in the conditional variance equation. Thus, the conditional variance model carries properties of autoregressive and moving averages together. In symmetrical ARCH and GARCH models, the effect of positive and negative shocks on variance is assumed to be the same. However, it has been observed that negative shocks, which represent bad news in financial markets in general, affect volatility more than positive shocks representing good 
news. Therefore, the EGARCH model, expressed as the exponential GARCH model by Nelson (1991), is developed from the point that the weaknesses neglected by symmetric models should be eliminated. The most important difference that distinguishes this model, which was first introduced by Black (1976) from symmetric models, is the existence of a leverage effect which is structured on the basis that negative news coming to the market affects volatility on financial assets more than positive news. This model has several advantages over the GARCH model. Since $\log \left(\sigma_{t}^{2}\right)$ is modeled first, even if the parameters are negative, $\left(\sigma_{t}^{2}\right)$ will be positive. Therefore, there is no need to impose artificially non-negative constraints on model parameters. Secondly, asymmetries are allowed under the EGARCH formula, because if the relationship between volatility and return is negative, it will be negative. In the original formulation, Nelson (1991) uses the Generalized Error Distribution (GED) structure for errors. GED is a very large distribution family that can be used for many series. But almost all EGARCH applications use conditional normal errors rather than using GED due to ease of calculation and intuitive interpretation (Brooks, 2008). By developing the EGARCH model, multivariate EGARCH models have emerged in the literature. The EGARCH model is shown as below:

$$
\log \left(\sigma_{t}^{2}\right)=\omega+\sum_{k=1}^{q} \beta_{k} g\left(Z_{t-k}\right)+\sum_{k=1}^{p} \alpha_{k} \log \sigma_{t-t}^{2}
$$

Volatility is modeled using the EGARCH method developed by Nelson (1991) in the study, due to the fact that asymmetry has a widespread leverage effect in stock returns and its non-negative constraint on GARCH parameters. The EGARCH model for stock returns is shown as below:

$$
\begin{array}{lll}
R_{t}=\alpha_{0}+\sum_{i=1}^{r} \quad \alpha_{i} R_{t-i}+\mu_{t} & \mu_{t} / \Omega_{t-1} \sim N\left(0, h_{t}\right) \\
\log \left(h_{t}\right)=\exp \left[\alpha_{0}+\sum_{i=1}^{q}\right. & a_{i} g\left(Z_{t-i}\right)+\sum_{i=1}^{p} & \left.b_{i} \log \left(h_{t-i}\right)\right] \\
g\left(Z_{t}\right)=\theta z_{t}+[\lfloor z t \mid-E[z t \mid] &
\end{array}
$$

In the equations above, $R_{t}$ means stock returns; $\mu_{t}$, the term stochastic error; $\Omega_{t-1}$ is the information set in the period $\mathrm{t}-1 ; h_{t}$ indicates conditional variance and $z_{t}$ standardized error term $\left(\mu_{t} / \sqrt{ } h_{t}\right)$. It is assumed that $h_{t}$ is normally distributed.

Equation (1) represents the conditional average equation, and (2) equation represents the conditional variance equation. According to the EGARCH model, variance is conditional to its lags and standardized error term. The stickiness of volatility is measured by $\sum_{i=1}^{p} \quad b_{i}$ shown in equation (2).

The second part of the equation (3) shows the effect of $\mathrm{ARCH}$, while the parameter $\theta$ represents the effect of the asymmetric $\mathrm{ARCH}$. If $\theta=0$, a positive shock has the same effect as a negative shock of similar size. In other words, the $\mathrm{ARCH}$ effect is symmetrical. If $0>\theta>$ -1 , a negative shock (bad news) increases volatility more than a positive shock (good news). Negative and statistically significant $\theta$ indicates the presence of leverage effect. Ljung-Box statistics of models estimated for $\mathrm{p}$ and $\mathrm{q}$ lags are taken into consideration in the selection of the EGARCH model for stock returns series for each country. 


\section{Analysis and Results}

Kanas (1998) has an approach based on the determination of volatility spread to emerging stock markets from the US, Germany, France and Japan stock markets. According to the Kanas (1998) approach, the most recent error squares obtained from the conditional averageconditional variance equations of developed markets are added to the conditional variance equation of the developing markets as an exogenous variable. Looking at the coefficient signs and their significance determines whether there is volatility or not.

Let us assume that the volatility spread from Dow Jones to Borsa İstanbul is examined by considering the EGARCH $(1,1)$ model.

$$
\log \left(h_{\text {BIST100,t }}\right)=\alpha_{0}+\theta_{1}\left(\frac{\mu_{t-i}}{\sqrt{h_{B I S T 100, t-1}}}\right)+\alpha_{1}\left|\frac{\mu_{t-i}}{\sqrt{h_{B I S T 100-1}}}\right|+\beta_{1} \log \left(h_{B I S T 100-1}\right)+\varphi_{1} \log \left(U_{D O W, t}\right)
$$

In equation (4) $\alpha_{1}$ shows the effect of $\mathrm{ARCH} ; \theta_{1}$, asymmetric $\mathrm{ARCH}$ effect; $\beta_{1}$ represents volatility stickiness and $U_{\text {DOW, }}$ t represents squares of error terms derived from the EGARCH model estimated for the USA. The volatility spread is determined by looking at the statistical significance of the $\varphi_{1}$ coefficient. If $\varphi_{1}$ the coefficient is statistically significant, the volatility spreads from the United State to Turkey.

High correlation occurs between all stock exchanges except Shanghai Composite Stock Exchange and S\&P 500 and it is positive as expected (APPENDIX 1). Augmented Dickey Fuller unit root analysis results are presented in Table 4.

Table 4

ADF Test results

\begin{tabular}{lcccc}
\hline Variables & t-Statistic & Prob.* & 1. Diff. & Prob.* \\
\hline BIST100 & $-1,205496$ & 0.6743 & -2.945 .833 & 0.0000 \\
DOW JONES & -0.621017 & 0.8636 & -1.705 .044 & 0.0000 \\
SP 500 & -1.047 .217 & 0.7382 & -5.775 .788 & 0.0001 \\
NIKKEI 225 & -1.028 .438 & 0.7452 & -5.716 .508 & 0.0001 \\
DAX & -1.198 .382 & 0.6774 & -5.489 .324 & 0.0001 \\
CAC40 & -2.036 .687 & 0.2711 & -5.621 .374 & 0.0001 \\
INDIA & -0.862377 & 0.8004 & -2.330 .561 & 0.0000 \\
SHANGHAI & -4.043 .100 & 0.0012 & -2.502 .041 & 0.0000 \\
INDONESIA & -1.367 .053 & 0.5999 & -5.231 .025 & 0.0001 \\
BOVESPA & -1.666 .819 & 0.4481 & -2.004 .786 & 0.0000 \\
\hline
\end{tabular}

Source: Author

Table 4 shows that all series sustain unit root at 1\% significance level. That is, they are not stationary and they become stationary at the first difference. Transformations are made for correction. Then, conditional mean equations are estimated by determining the appropriate ARIMA model for each series. The most suitable ARMA models are presented in Table 5. 
Table 5

ARMA Test Results

BIST100

BOVESPA

INDIA

INDO

SHANGHAI

NIKKEI

CAC40

DAX

SP500

DOW

\begin{tabular}{lcc}
\hline & MODEL & AIC Value \\
\hline 2 & 0 & $-5,4172$ \\
4 & 0 & $-5,1689$ \\
4 & 0 & $-5,6717$ \\
4 & 0 & $-5,8679$ \\
3 & 0 & $-5,4569$ \\
2 & 0 & 13,5984 \\
2 & 0 & $-5,3167$ \\
4 & 0 & $-5,6513$ \\
0 & 0 & $-3,5191$ \\
3 & 0 & $-5,9099$ \\
\hline
\end{tabular}

Source: Author

Heteroscedasticity is not a cross-sectional data problem. Also, autoregressive conditional heteroscedasticity occurs in time series data. The reason to model a series with ARCH/ GARCH models is that one does not model it with linear methods. This type of data has the characteristics of leptokurtosis, volatility clustering, long memory and leverage effect. Heteroscedasticity and $\mathrm{ARCH}$ effect are valid for all countries and test results are presented below in Table 6.

\section{Table 6}

ARCH LM Test Results

BIST100

BOVESPA

INDIA

INDO

SHANGHAI

NIKKEI

CAC40

DAX

SP500

DOW

Source: Author

\begin{tabular}{cc}
\hline F-statistic & Prob. \\
\hline 504912,8 & 0,0000 \\
363014,8 & 0,0000 \\
574535,7 & 0,0000 \\
1126815 & 0,0000 \\
201903,6 & 0,0000 \\
296459,5 & 0,0000 \\
160950,7 & 0,0000 \\
183279,6 & 0,0000 \\
144604,8 & 0,0000 \\
477280,9 & 0,0000
\end{tabular}

ARCH graphics are presented in APPENDIX 2. The changes of Borsa Istanbul, NIFTY 50 - India, Jakarta- Indonesia, French, German and Tokyo Stock Market Exchange - Japan are symmetrical. Although the Dow Jones Industrial Average Index - USA, S\&P 500 Index - USA and Brazil Stock Exchange differ, their volatility spread in 2020 are exactly the same except Shanghai Composite Stock Exchange - China. All stock exchanges started by rising to 2020 At the beginning of 2020, all stock markets rose and dropped very quickly after the Corona Virus was declared an epidemic by the World Health Organization. Interestingly, the volatility of Shanghai Stock Exchange remains stable even though the virus started in China in December 2019. As shown in the correlation table, the Shanghai Composite Stock Exchange and S\&P 500 Index behave completely differently. 
EGARCH model estimation results for the return series of exchanges are given in Table 7. Conditional variance models are determined as EGARCH $(1,1)$.

Table 7

EGARCH Test Results

\begin{tabular}{lccccc}
\hline \multicolumn{1}{c}{ Variables } & $\boldsymbol{\varphi}$ & $\boldsymbol{\mu}$ & $\boldsymbol{\eta}$ & $\boldsymbol{\lambda}$ & $\boldsymbol{\theta}$ \\
\hline BIST100 & 0.386739 & 0,065808 & 0.153447 & -0.058635 & 0.963805 \\
BOVESPA & 0.194434 & 0,040915 & 0.150435 & -0.058525 & 0.977478 \\
INDIA & 0.190546 & 0,036629 & 0.152999 & -0.123520 & 0.964244 \\
INDO & 0.120525 & 0,027029 & 0.149068 & -0.080943 & 0.969199 \\
SHANGHAI & -0.050041 & 0,007068 & 0.121020 & 0.014922 & 0.994689 \\
NIKKEI & 0.147437 & 0,035851 & 0.188447 & -0.079969 & 0.972452 \\
CAC40 & 0.230189 & 0,025245 & 0.118560 & -0.173844 & 0.958782 \\
DAX & 0.179792 & 0.0273370 & 0.135230 & -0.108743 & 0.969413 \\
SP 500 & 4.537 .190 & 0.0001620 & 9.445 .853 & -6.805 .739 & 0.383239 \\
DOW & 0.215775 & 0.031793 & 0.227569 & -0.148013 & 0.960549 \\
\hline
\end{tabular}

Source: Author

When the EGARCH model conditional equation of variance, which is a function of past knowledge and conditional variance, is examined, it is understood from the coefficients that similar to the return spread, information shocks also spread asymmetrically across countries in a multi-directional manner and that most of them are statistically significant. The asymmetric effect parameter ( $\lambda$ or $\mu \mathrm{t}-\mathrm{i} / \mathrm{ht}-1)$ appears to be negative and statistically significant at $1 \%$ for all countries, except Shanghai Composite Stock Exchange (prob. 0.1165). This shows that the asymmetric effect, or in other words, the leverage effect, is valid in the stock markets other than China. The a symmetrical effect indicates that bad news increases stock return volatility more than good news. In addition, the volatility stickiness parameter is very close to zero for emerging markets. S\&P 500 is the stock market in which the volatility stickiness has the highest value. BIST 100 has the highest value of the volatility stickiness. The volatility stickiness parameter indicates that a volatility shock in the $\mathrm{t}-1$ period can have a long-term effect on the conditional variance in the t period. Also, Ljung-Box (LB) statistics for standardized error terms and squares obtained from EGARCH models show that error terms are not autocorrelated and the $\mathrm{ARCH}$ effect does not remain in the error terms, respectively.

The volatility spreads from Dow Jones Industrial Average Index - USA to Borsa Istanbul and Shanghai Stock Exchange - China. Also, the S\&P 500 is significant on the volatility spread of Borsa Istanbul and Shanghai Composite Stock Exchange. DAX, CAC40 and NIKKEI have no effects on the volatility spread n emerging countries (Table 8). BOVESPA's volatility is affected by only the Dow Jones Industrial Average Index - USA. There is no effect of volatility spread in NIFTY 50 - India and Jakarta- Indonesia. 
Table 8

Volatility Spread in Emerging Markets

\begin{tabular}{lccccc}
\hline Variables & DOW & SP500 & DAX & CAC40 & NIKKEI \\
\hline BIST100 & $\mathbf{0 , 0 0 0 0}$ & $\mathbf{0 , 0 0 0 6}$ & 0,6229 & 0,7044 & 0,1968 \\
BOVESPA & $\mathbf{0 , 0 0 0 4}$ & 0,8086 & 0,1622 & 0,8335 & 0,0549 \\
INDIA & 0,5367 & 0,6488 & 0,7923 & 0,7166 & 0,3052 \\
INDO & 0,0676 & 0,9996 & 0,2163 & 0,3468 & 0,7644 \\
SHANGHAI & $\mathbf{0 , 0 0 2 4}$ & $\mathbf{0 , 0 1 8 8}$ & 0,0945 & 0,0909 & 0,2908 \\
\hline
\end{tabular}

Source: Author

The volatility spread between Jakarta Stock Exchange - Indonesia and Borsa Istanbul is two-way and mutual. Also, the volatility on the NIFTY 50 - India Stock Market Index affects Borsa Istanbul and Jakarta Stock Exchange - Indonesia. Interestingly, the Brazil Stock Exchange has an effect on NIFTY 50 - India Stock Market Index. Surprisingly, Shanghai Composite and Brazil Stock Exchange have no effects on the volatility spreads in emerging countries (Table 9). China's stock markets are dominated by domestic investors. Foreign investors owned an estimated $7.3 \%$ of the stock market capitalization on China's domestic equity market, according to UBS estimates. Even though China is open to the outside, it is still ruled by the socialist central committee government. Also, Hong Kong faces social and political problems such as human rights marches. Most recently, Hong-Kong has had international problems with connecting to itself. Therefore, the country's stock market is very open to government intervention. Hence, it is considered to be outside the volatility spread effect.

Table 9

Volatility Spread between Emerging Markets

\begin{tabular}{lccccc}
\hline Variables & BIST100 & BOVESPA & INDIA & INDO & SHANGHAI \\
\hline BIST100 & - & 0,0808 & $\mathbf{0 , 0 0 0 0}$ & $\mathbf{0 , 0 0 0 0}$ & 0,1165 \\
BOVESPA & 0,3771 & - & 0,1612 & 0,9008 & 0,8086 \\
INDIA & 0,0625 & $\mathbf{0 , 0 0 0 1}$ & - & 0,0649 & 0,0810 \\
INDO & $\mathbf{0 , 0 0 0 1}$ & 0,2568 & $\mathbf{0 , 0 0 2 1}$ & - & 0,5678 \\
SHANGHAI & 0,0810 & 0,4996 & 0,4075 & 0,8691 & - \\
\hline
\end{tabular}

Source: Author

\section{Conclusion}

This article provides a discussion on volatility spread in emerging markets. The theories based on the Modern Portfolio Theory of Harry Markowitz and the innovations that emerged in the field of technology and communication in the 1990s gave a significant impetus to the speed of integration of financial markets. Thus, the direction and the size of the interaction between the markets increases each day. This situation leads to a differentiation in the risk 
and return perceptions of current and potential investors in the markets due to systematic and nonsystematic risk factors. Risk also causes fluctuations in the prices of financial assets, which are described as volatility in the literature.

Volatility and uncertainties in financial markets affect developing economies in more depth. It is a known fact that developing countries are open to risks. In addition, the fact that the negative news coming from the market has a greater impact compared to the positive news creates a multiplier effect, namely a leverage effect, and increases the risks for the investors. It is noteworthy that after the global 2008 financial crisis that emerged in the USA, there was a significant level of volatility spread from the USA. Also, the CoronaVirus (COVID-19) epidemic that emerged in China in December 2019 and affected almost the whole world, has also turned all markets upside down, from stock exchanges to oil prices, from interest rates to gold prices. There is a CoronaVirus shock in the markets. In fact, the term collapse can also be used. ARCH graphics in APPENDIX 2 clearly show that there is a huge volatility spread in all markets. On Thursday, March 12, 2020, the US Stock Exchange made their strongest decline since 1987. VIX Index, or the Chicago Board Options Exchange Volatility Index, that shows the uneasiness and volatility in the markets has reached its highest level since the 2008 global crisis period. Time is needed to build trust again. Expectations are distorted, and expectations for a slowdown and stagnation prevail in the global economy. The USA and Europe have revised their annual growth expectations downwards. Economic data have already started to deteriorate in Japan and China. Countries including Turkey continue CoronaVirus (COVID-19) measures related to everyday life. Interest rates will remain low for a long time. Oil and commodity prices have declined. Low interest and abundant liquidity will not be a solution this time. It is time to think about new solutions and new models.

The study proves that the asymmetric effect parameter ( $\lambda$ or $\mu \mathrm{t}-\mathrm{i} / \mathrm{ht}-1)$ appears to be negative and statistically significant at $1 \%$ for all countries, except the Shanghai Composite Stock Exchange. This shows that the asymmetric effect, in other words the leverage effect, is valid in stock markets other than in China. The volatility spreads from Dow Jones Industrial Average Index - USA to Borsa Istanbul and Shanghai Stock Exchange - China. Also, S\&P 500 Index - USA is significant for the volatility spread of Borsa Istanbul and Shanghai Stock Exchange. The volatility spread between Jakarta Stock Exchange - Indonesia and Borsa Istanbul is two-way and mutual. The European region stock markets do not have a significant effect on the emerging economies.

Moreover, the contagion effect is present in emerging markets. In particular, there is a volatility spillover from the US stock markets to the stock markets of developing countries. Such a result is normal when all eyes of the world are on the USA and the US Federal Reserve. The USA is still the world's financial giant. There is also a contagion and volatility spread among developing countries. Although countries have their own macroeconomic determinants and risks, it has been seen that financial markets act together instantly with financial globalization. 
Finally, future studies would be to determine the volatility spread for all or other emerging markets and to observe the volatility spread and financial contagion together or separately during the Coronavirus (COVID-19) period.

\section{References}

Abou-Zaid, A. S. (2011). Volatility spillover effects in emerging MENA stock markets. Review of Applied Economics, 7(1076-2016-87178), 107-127.

Akgün, I. \& Sayyan, H. (2007). İMKB-30 hisse senedi getirilerinde volatilitenin kısa ve uzun hafizalı asimetrik koşullu değişen varyans modelleri ile öngörüsü. Iktisat Isletme ve Finans, 22(250), 127-141.

Baillie, R. T., \& DeGennaro, R. P. (1990). Stock returns and volatility. Journal of financial and Quantitative Analysis, 25(2), 203-214.

Bala, D. A., \& Takimoto, T. (2017). Stock markets volatility spillovers during financial crises: A DCCMGARCH with skewed-t density approach. Borsa Istanbul Review, 17(1), 25-48.

Bala, L. \& Premaratne, G. (2004). Volatility spillover and co-movement: some new evidence from Singapore. In Midwest Econometrics Group (MEG) Fall Meetings North Western University Evanston.

Baykut, E., \& Kula, V. (2018). Borsa İstanbul pay endekslerinin volatilite yapısı: BİST-50 örneği (2007-2016 y1llar1). Afyon Kocatepe Üniversitesi Sosyal Bilimler Dergisi, 20(1), 279-303.

Bayramoglu, M. F., \& Abasiz, T. (2017). Gelismekte Olan Piyasa Endeksleri Arasinda Volatilite Yayilim Etkisinin Analizi/Analysis of Volatility Spreading Effect Between Developing Market Indices. Muhasebe ve Finansman Dergisi, (74).

Black, F. (1976). Studies of stock market volatility changes. Proceedings of the American Statistical Association Business and Economic Statistics Section.

Bollerslev, T. (1986). Generalized autoregressive conditional heteroskedasticity. Journal of econometrics, 31(3), 307-327.

Brooks, C. (2019). Introductory econometrics for finance. Cambridge university press.

Büberkökü, Ö. (2013). Kriz döneminde yükselen piyasa ekonomileri, Euro bölgesi ve ABD piyasaları arasındaki volatilite yayılmasının incelenmesi: Varyansta-granger-nedensellik testinden kanıtlar. In EY International Congress on Economics I (EYC2013), October 24-25, 2013, Ankara, Turkey (No. 208). Ekonomik Yaklasim Association.

Çağıl, G., \& Okur, M. (2010). 2008 Küresel Krizinin İmkb Hisse Senedi Piyasasi Üzerindeki Etkilerinin Garch Modelleri İle Analizi. Marmara Üniversitesi İktisadi ve İdari Bilimler Dergisi, 28(1), 573-585.

Çelik, İ., Özdemir, A., \& Gülbahar, S. D. (2018). Gelişmekte Olan Ülkelerde Getiri ve Volatilite Yayılımı: NIMPT Ülkelerinde VAR-EGARCH Uygulamas1. Finans Politik \& Ekonomik Yorumlar, 55(636), 9-24.

Dedi, L., \& Yavaş, B. F. (2016). Return and volatility spillovers in equity markets: An investigation using various GARCH methodologies. Cogent Economics \& Finance, 4(1), 1266788.

Değirmenci, N. \& Abdioğlu, Z. (2017), Finansal piyasalar arasındaki oynaklık yayılımı. Dumlupınar Üniversitesi Sosyal Bilimler Dergisi, (54), 107-125. 
Demir, İ., \& Çene, E. (2012). IMKB 100 endeksindeki kaldıraç etkisinin ARCH modelleriyle iki alt dönemde incelenmesi/Investigating leverage effect on Turkish stock market with ARCH models within two subgroups. Istanbul Üniversitesi Işletme Fakültesi Dergisi, 41(2), 214.

Demirgil, H., \& Gök, İ. Y. (2014). Türkiye Ve Başlıca AB Pay Piyasaları Arasında Asimetrik Volatilite Yay11ımı. Yönetim ve Ekonomi Araştırmaları Dergisi, 12(23), 315-340.

Demirhan, D. (2013). Stock market reaction to national sporting success: case of Borsa Istanbul. Pamukkale Journal of Sport Sciences, 4(3).

Doğanay, M. M. (2003). İMKB DİBS Fiyat Endekslerinin Volatilite ve Kovaryanslarının Öngörülmesi. IMKB Dergisi, 27, 17-37.

Dornbusch, R., Park, Y. C., \& Claessens, S. (2000). Contagion: How it spreads and how it can be stopped. World Bank Research Observer, 15(2), 177-197.

Duran, S., \& Şahin, A. (2006). İMKB Hizmetler, Mali, Sınai ve Teknoloji Endeksleri Arasındaki İlişkinin Belirlenmesi. Gaziosmanpaşa Üniversitesi Sosyal Bilimler Araştırmaları Dergisi, 13, 1,57-70.

Engle, R. F. (1982). Autoregressive conditional heteroscedasticity with estimates of the variance of United Kingdom inflation. Econometrica: Journal of the Econometric Society, 987-1007.

Engle, R. F., Lilien, D. M., \& Robins, R. P. (1987). Estimating time varying risk premia in the term structure: The ARCH-M model. Econometrica: journal of the Econometric Society, 391-407.

Engle, R. F., Gallo, G. M., \& Velucchi, M. (2012). Volatility spillovers in East Asian financial markets: a MEM-based approach. Review of Economics and Statistics, 94(1), 222-223.

Er, Ş. \& Fidan, N. (2013). Modeling Istanbul Stock Exchange-100 Daily Stock Returns: A Nonparametric GARCH Approach. Journal of Business, Economics \& Finance, 2(1), 36-50.

Eryılmaz, F. (2015). Modelling Stock Market Volatility: The Case Of BIST-100. Annals of' Constantin Brancusi' University of Targu-Jiu. Economy Series, (5).

Evlimoğlu, U. \& Çondur, F. (2012). İMKB ile Bazı Gelişmiş ve Gelişmekte Olan Ülke Borsaları Arasındaki Karşılıklı Bağlantıların Küresel Kriz Öncesi ve Sonrası Dönem İçin İncelenmesi. Uludağ Üniversitesi İktisadi ve İdari Bilimler Fakültesi Dergisi, 31(1), 31-58.

Eun, C. S., \& Shim, S. (1989). International transmission of stock market movements. Journal of financial and quantitative Analysis, 24(2), 241-256.

French, K. R., Schwert, G. W., \& Stambaugh, R. F. (1987). Expected stock returns and volatility. Journal of financial Economics, 19(1), 3.

Fry, R., Martin, V. L., \& Tang, C. (2008). A new class of tests of contagion with applications to real estate markets. Centre For Applied Macroeconomics Analyses Working Paper Series, 1.

Gökbulut, R., \& Pekkaya, M. (2014). Estimating and Forecasting Volatility of Financial Markets Using Asymmetric GARCH Models: An Application on Turkish Financial Markets. International Journal of Economics and Finance, 6 (4), 23-33. http://dx.doi.org/10.5539/ijef.v6n4p23

Gujarati, D. (2011). Econometrics by Example. Palgrave Macmillan.

Gümrah, S. Ç. G. Ü., Çukur, S., \& Gümrah, Ü. (2012). İstanbul Menkul Kiymetler Borsasinda Hisse Senedi Getirileri Ve İşlem Hacmi İlişkisi. Niğde Üniversitesi İktisadi Ve İdari Bilimler Fakültesi Dergisi, 5(1), 20-35.

Güriş, S. \& Saçildi, İ. S. (2011). İstanbul Menkul Kiymetler Borsası'nda Hisse Senedi Getiri Volatilitesinin Klasik Ve Bayesyen Garch Modelleri İle Analizi. Trakya Üniversitesi Sosyal Bilimler Dergisi, 13(2), 153-171. 
Gürsoy, M. \& Balaban, M. (2014). Hisse Senedi Getirilerindeki Volatilitenin Tahminlenmesinde Destek Vektör Makinelerine Dayali Garch Modellerinin Kullanimi. Kafkas Üniversitesi İktisadi ve İdari Bilimler Fakültesi Dergisi, 5(8), 167-186.

Hamao, Y., Masulis, R. W., \& Ng, V. (1990). Correlations in price changes and volatility across international stock markets. The review of financial studies, 3(2), 281-307.

Islam, R., Islam, M. T., \& Chowdhury, A. H. (2013). Testing for global volatility spillover, financial contagion and structural break in fifteen economies from two regions: a diagonal VECH matrix and EGARCH $(1,1)$ approach. International Journal of Economics and Finance, 5(5), 159-170.

Joshi, P. (2011). Return and volatility spillovers among Asian stock markets. Sage Open, 1(1), 1-8.

Kanas, A. (1998). Volatility spillovers across equity markets: European evidence. Applied financial economics, 8(3), 245-256.

Karabacak, M., Meçik, O., \& Genç, E. (2014). Koşullu Değişen Varyans Modelleri ile BİST 100 Endeks Getirisi ve Altın Getiri Serisi Volatilitesinin Tahmini. Journal of Alanya Faculty of Business/Alanya İsletme Fakültesi Dergisi, 6(1), 79-90.

Kırkulak Uludag, B., \& Ezzat, H. (2017). Volatility Spillover Effect in MENA Stock Markets: Evidence from Pre-and Post-Egyptian Revolution. Journal of Yasar University, 12(45), 32-47.

Kishor, N., \& Singh, R. P. (2014). Stock return volatility effect: Study of BRICS. Transnational Corporations Review, 6(4), 406-418.

Kocabaş, C. (2019). Testing for Contagion in Economic Literature. Journal of Governance and Regulation, $8(3)$.

Kutlar, A., \& Torun, P. (2013). İMKB 100 Endeksi Günlük Getirileri İçin Uygun Genelleştirilmiş Farkli Varyans Modelinin Seçimi. Erciyes Üniversitesi İktisadi ve İdari Bilimler Fakültesi Dergisi, (42), 1-24.

Lee, S. J. (2009). Volatility spillover effects among six Asian countries. Applied Economics Letters, 16(5), 501-508.

Li, Y., \& Giles, D. E. (2015). Modelling volatility spillover effects between developed stock markets and Asian emerging stock markets. International Journal of Finance \& Economics, 20(2), 155-177.

Majdoub, J., \& Mansour, W. (2014). Islamic equity market integration and volatility spillover between emerging and US stock markets. The North American Journal of Economics and Finance, 29, 452-470.

Masson, M. P. R. (1998). Contagion: Monsoonal effects, spillovers, and jumps between multiple equilibria (No. 98-142). International Monetary Fund.

McMillan, D. G., Berke, B., \& Bajo-Rubio, O. (2016). The Behaviour of Asset Return and Volatility Spillovers in Turkey: A Tale of Two Crises. Available at SSRN 2832803.

Miyakoshi, T. (2003). Spillovers of stock return volatility to Asian equity markets from Japan and the US. Journal of International Financial Markets, Institutions and Money, 13(4), 383-399.

Nelson D. (1991). Conditional Heteroskedasticity in Asset Returns: A New Approach. Econometrica, 59(2), $347-370$.

Özer, M., Kamışl1, S. \& Kamışl1, M. (2016). Are volatility spillovers among G7 stock markets symmetric or asymmetric. Proceedings of the 7th European Business Research Conference, 15-16 December, University of Roma Tre, Roma, Italya.

Qian, P. Y., \& Diaz, J. F. (2017). Volatility integration of global stock markets with the Malaysian stock market: A Multivariate GARCH approach. Malaysian Journal of Economic Studies, 54(1), 83-117.

Samırkaş, M. C. \& Düzakın, H. (2013). İstanbul Menkul Kıymetler Borsasının Avrasya Borsaları ile Entegrasyonu. Akademik Bakış Dergisi, 35(25), 1-19. 
Sevüktekin, M., \& Nargeleçekenler, M. (2006). İstanbul Menkul Kiymetler Borsasinda Getiri Volatilitesinin Modellenmesi Ve Önraporlanmasi. Ankara Üniversitesi SBF Dergisi, 61(4), 243-265.

Sheng, H. C. \& Tu, A. H. (2000). A study of cointegration and variance decomposition among national equity indices before and during the period of the Asian financial crisis. Journal of Multinational Financial Management, 10(3-4), 345-365.

Shin, J. (2005). Stock returns and volatility in emerging stock markets. International Journal of Business and economics, 4(1), 31 .

Syriopoulos, T., Makram, B. \& Boubaker, A. (2015). Stock market volatility spillovers and portfolio hedging: BRICS and the financial crisis. International Review of Financial Analysis, 39, 7-18.

Theodossiou, P. \& Lee, U, (1995). Relationship between Volatility and Expected Returns across International Stock Markets. Journal of Business Finance and Accounting, 22(2), 289-300.

Tülin, A. (2009). İstanbul Menkul Kıymetler Borsasında Değişkenliğin (Volatilitenin) ARCH-GARCH Yöntemleri ile Modellenmesi. İstanbul Üniversitesi, Işsletme Fakültesi, İşletme İktisadı Enstitüsü Yönetim Dergisi, (62).

Tripathy, N., \& Garg, A. (2013). Forecasting stock market volatility: Evidence from six emerging markets. Journal of International Business and Economy, 14(2), 69-93.

Xie, S., \& Huang, X. (2013). An empirical analysis of the volatility in the open-end fund market: Evidence from China. Emerging Markets Finance and Trade, 49(sup4), 150-162.

Xiao, L., \& Dhesi, G. (2010). Volatility spillover and time-varying conditional correlation between the European and US stock markets. Global Economy and Finance Journal, 3(2), 148-164.

Yıldız, B. (2016). Oynaklık Tahmininde Simetrik ve Asimetrik GARCH Modellerinin Kullanılması: Seçilmiş BİST Alt Sektör Endeksleri Üzerine Bir Uygulama. Journal of Accounting \& Finance, 72.

Yonis, M. (2011). Stock market co-movement and volatility spillover between the USA and South Africa.

Yorulmaz, Ö. \& Ekinci, O. (2010). İMKB`nin Latin Amerika Borsalariyla İlişkisi Üzerine Çok Değişkenli GARCH Modellemesi. Sosyal Bilimler Dergisi, (1), 25-32. 


\section{APPENDIX 1}

\section{Correlation Matrix}

\begin{tabular}{|c|c|c|c|c|c|c|c|c|c|c|}
\hline & BIST100 & BOVESPA & CAC40 & DAX & INDIA & INDO & NIKKEI & SHANGAI & SP500 & DOW \\
\hline BIST100 & 1 & 0.6082 & 0.7993 & 0.9156 & 0.9158 & 0.9494 & 0.8076 & 0.1718 & 0.3923 & 0.9073 \\
\hline BOVESPA & 0.6082 & 1 & 0.6206 & 0.5239 & 0.6914 & 0.5435 & 0.5536 & 0.1812 & 0.4414 & 0.7072 \\
\hline CAC40 & 0.7993 & 0.6206 & 1 & 0.9099 & 0.8937 & 0.7699 & 0.9246 & & & 0.8869 \\
\hline DAX & 0.9156 & 0.5239 & 0.9099 & 1 & 0.9427 & 0.9461 & 0.9188 & 0.9349 & 0.3059 & 0.3323 \\
\hline INDIA & 0.9158 & 0.6914 & 0.8937 & 0.9427 & 1 & 0.9132 & 0.9147 & 0.2970 & 0.3869 & 0.9729 \\
\hline INDO & 0.9493 & 0.5435 & 0.7699 & 0.9461 & 0.9132 & 1 & 0.7976 & 0.1337 & 0.2620 & 0.9081 \\
\hline NIKKEI & 0.8075 & 0.5536 & 0.9246 & 0.9188 & 0.9147 & 0.7976 & 1 & 0.4008 & 0.3503 & 0.9265 \\
\hline SHANGAI & 0.1718 & 0.1812 & 0.4910 & 0.9349 & 0.2970 & 0.1337 & 0.4008 & 1 & 0.0586 & 0.2136 \\
\hline SP500 & 0.3923 & 0.4414 & 0.3365 & 0.3059 & 0.3869 & 0.2620 & 0.3503 & 0.0586 & 1 & 0.4277 \\
\hline DOW & 0.9073 & 0.7072 & 0.8869 & 0.3323 & 0.9729 & 0.9081 & 0.9265 & 0.2136 & 0.4277 & 1 \\
\hline
\end{tabular}




\section{APPENDIX 2}

\section{ARCH LM Test Graphics}
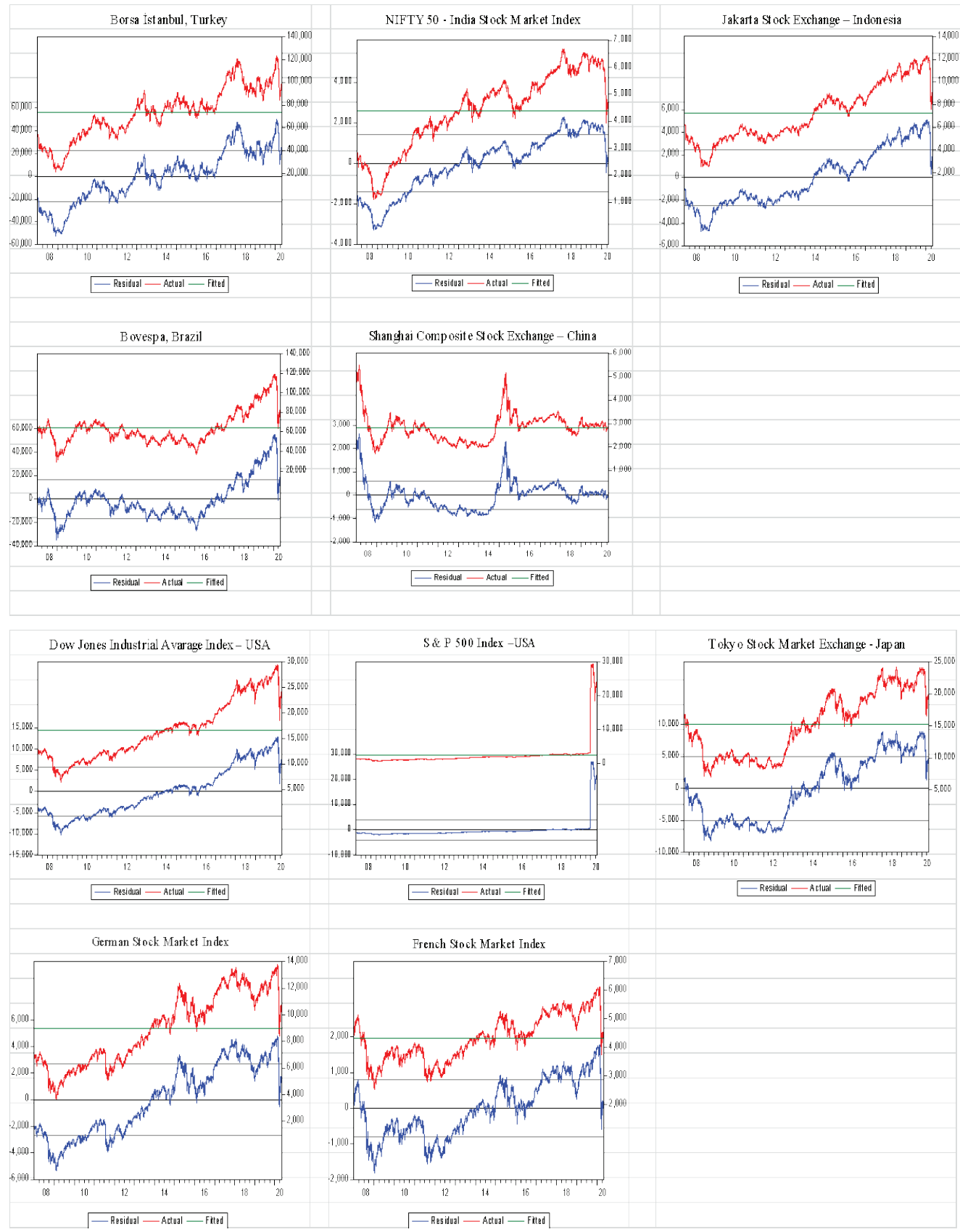
